\title{
Ready for global success? Strengths and weaknesses of Korean HRM
}

\author{
Fabian Jintae Froese ${ }^{1}$
}

Published online: 18 March 2020

(C) The Author(s) 2020

\begin{abstract}
Fueled by a highly dedicated and highly skilled workforce, South Korea (henceforth Korea) has enjoyed tremendous economic growth and developed numerous successful global companies. In the past, Korean companies benchmarked Japanese and US HR practices. However, Korean companies are now at the crossroads, facing slowing economic growth rates, an aging population, changing gender roles, and an increase in foreign employees. This article reviews the strengths and weaknesses of Korean HRM and presents some tentative recommendations how Korean companies can respond to these challenges. If Korean companies intend to continue their global success, they are recommended to adapt their staffing strategy, organizational culture, and corporate language policies to embrace an increasingly diverse workforce.
\end{abstract}

Keywords Korea · Human resource management - Global talent management . Human resource practices $\cdot$ Staffing $\cdot$ Organizational culture

\section{Introduction}

As a country lacking natural resources, it is astonishing how rapidly South Korea (henceforth Korea) catapulted itself from a poor, developing country in the 1960s into an industrialized economy within a few decades. One of the main drivers for this miraculous development is the highly dedicated and highly skilled Korean workforce. Thus, studying human resource management (HRM) in Korea is a fruitful activity to better understand the underlying reasons for the nation's success.

In line with socio-economic changes, Korean HRM evolved in three phases (Froese 2019): pre-1987, 1987-1997, and post-1997. In the first phase, Korea was under a strict military regime and enjoyed high economic growth rates. Confucianism and Japanese HRM greatly influenced Korean HRM resulting in a seniority-based system and lifetime employment. The second phase was characterized by globalization

Fabian Jintae Froese

ffroese@uni-goettingen.de

1 University of Goettingen, Goettingen, Germany 
and political democratization in Korea. This led to a competence-based HRM and the emergence of labor unions. The third phase was triggered by the Asian financial crisis in 1997. Numerous companies and private households went bankrupt. In response, the Korean government complied with recommendations by the IMF and the US to restructure the economy, including deregulation and dismantling of Korean conglomerates. In the wake of these changes, Korean companies adopted a US-style performance-based HRM system and flexible labor markets.

Korean has entered the fourth phase. Korean companies have assumed important roles in the global economy, e.g., 16 Korean companies belong to the Fortune 500 list of the largest companies in the world. Meanwhile, medium economic growth rates, declining demography, changing gender roles, and an influx of immigrants at home present major challenges for the management of Korean companies. What are the consequences for Korean HRM? In this commentary, I analyze the strengths and weaknesses of Korean HRM and provide some tentative conclusions how Korean companies can manage today's challenges.

\section{Strengths}

Korean companies have adopted Japanese and US practices, and partly formed their hybrid HR practices blending these different influences with its indigenous origins. Compared to Japanese companies, Korean companies have more aggressively embraced US practices (Froese et al. 2018). Korean companies have largely adopted "high performance" and "high commitment" HRM systems, emphasizing HR practices that motivate employees, develop abilities, and provide opportunities (Jiang et al. 2012).

In his seminal paper, Hemmert (2020) identified three major strengths of Korean HRM. First, Korean companies tend to have a highly systematic recruiting system. Korean companies invest heavily in employer branding and conduct sophisticated tests and multiple rounds of interviews to select suitable candidates. While Korean companies prefer to hire entry-level candidates, they also actively hire talent at mid and higher levels. Fit between the organizational culture and candidate values is important. Second, rooted in Confucianism, Korean companies have placed heavy emphasis on employee training and development. They combine various on-the-job and sophisticated off-the-job trainings. Most medium and large Korean companies maintain their own training centers and offer various training programs specifically tailored to different employees. In addition, they cooperate with external educational institutes and universities. Some companies offer sponsored executive training and MBA programs to motivate high performers. While the budget for training has declined in recent years, Korean companies tend to provide more training to their employees than most companies from other countries (Hemmert 2020). Third, Korean companies have developed a hybrid system of seniority and a performancebased system of pay and promotion. Although Korean companies originally adopted the Japanese seniority system, Korean companies have aggressively adopted 
performance-based pay and promotion. Individual performance-based bonus payments, fast-track promotion, and profit-sharing systems have become widespread. At the same time, some elements of seniority linger on.

\section{Weaknesses}

The Korean HRM system is well suited for a homogenous Korean workforce in a growing economy. However, the workforce of Korean companies is becoming increasingly diverse, at home and abroad due to external pressures (Froese et al. 2018). More non-Koreans and women work for Korean companies. While the diversity literature discusses various other diversity characteristics, I will focus on these two groups of employees in this commentary, because they are the most prominent groups in Korean companies. The changing demographic makeup of the workforce reveals the following weaknesses in the Korean HRM system.

First, Korean companies have a very traditional staffing approach, mainly promoting Korean men to upper management positions. Senior Korean male managers and owners have preferred to put Korean men into upper management positions. The percentage of women and non-Koreans on the top management team of Korean companies is well below 5\%, which is well below compared to other major industrialized countries. This ethnocentric staffing approach discourages talented women and foreigners to aspire management careers in Korean companies. Second, while selected Korean HR practices have adopted US and Japanese influence, the organizational culture has changed little during the past decades. The corporate cultures of most Korean companies can be characterized by strict hierarchies, collectivism, paternalistic leadership styles, and long working hours. These traits are not compatible with a diverse workforce. In particular, strict hierarchies are problematic for most non-Korean workers, who are used to flat hierarchies, discussions, and joint decision-making. For women taking care of children and/or parents, long working hours are very difficult to combine with their other duties. Further, these long working hours are not matched by pay and productivity. Korea ranks very low among OECD members for labor compensation and productivity per hour worked (OECD 2020). This has implications for foreign talent attraction, especially for those from Western countries who are used to being paid well for their time. Third, the corporate language of most Korean companies is Korean. However, Korean is not widely spoken outside of Korea. This severely limits the communication with foreign subsidiaries, employees, suppliers, and customers and limits the career opportunities for non-Korean managers. Offering foreign language courses to Korean managers is not a sufficient solution. These communication difficulties eventually lead to employee dissatisfaction and employee turnover (Froese et al. 2016). 


\section{Conclusion}

Korea has enjoyed tremendous economic success. However, the continued international expansion of Korean companies and socio-economic changes at home put severe pressures on the sustainable global success of Korean companies. If Korean companies intend to continue their global success, change is inevitable. Korean policy makers and companies should engage in concerted efforts to modify the HRM system to embrace a diverse workforce at home and abroad. Towards that goal, Korean companies can build on their HRM strengths (Hemmert 2020), i.e., systematic recruiting, emphasis on training, performance-based pay and promotion, and work on their weaknesses (Froese et al. 2018), i.e., ethnocentric staffing, traditional corporate culture, and Korean corporate language.

While ethnocentric staffing strategies are common among companies with little international experience, it is time for Korean companies to step up. Some Korean companies have started to increasingly hire foreign talent in senior positions in their foreign subsidiaries. In a next step, Korean companies should develop global talent pools, including both Korean and non-Korean talent, and develop them to top management positions. Meanwhile, Korean government-related organizations have increasingly hired women into important functions. Long-term staffing strategies are essential to systematically recruit, support, and develop non-Koreans and women into top management positions.

Although the tight corporate cultures of Korean companies were considered a unique strength in the past, these are not compatible with an increasingly diverse workforce. Korean companies should consider reducing hierarchies and be open towards different mindsets. This would not only improve the satisfaction of employees with diverse backgrounds but also have the potential to spur innovation. The Korean government has recently imposed a 52-h workweek system. This is a promising step to limit excessive work-hours and improve work-life balance of employees, thus allowing employees pursuing both careers and family life. Beyond government regulations, Korean companies and managers should actively support women (and others who hold additional family and household duties) to combine work and life.

Several Korean companies have already started introducing English as a corporate language but with mixed results. All globally operating Korean companies should seriously consider introducing English as their corporate language. This would improve communication with non-Korean clients, suppliers, and employees. Most German and even French multinational companies have introduced English as their corporate language. Granted, the general English proficiency in Korea is rather low. Thus, the education system in Korea should further promote learning English. Korean companies could gradually introduce English as the corporate language by using English as selection criterion and providing English training, and the opportunity to use English at work. 
Open Access This article is licensed under a Creative Commons Attribution 4.0 International License, which permits use, sharing, adaptation, distribution and reproduction in any medium or format, as long as you give appropriate credit to the original author(s) and the source, provide a link to the Creative Commons licence, and indicate if changes were made. The images or other third party material in this article are included in the article's Creative Commons licence, unless indicated otherwise in a credit line to the material. If material is not included in the article's Creative Commons licence and your intended use is not permitted by statutory regulation or exceeds the permitted use, you will need to obtain permission directly from the copyright holder. To view a copy of this licence, visit http://creativecommons.org/licen ses/by/4.0/.

\section{References}

Froese, F. J. (2019). Doing business in Korea. London: Routledge.

Froese, F. J., Kim, K., \& Eng, A. (2016). Language, cultural intelligence, and inpatriate turnover intentions: Leveraging values in multinational corporations through inpatriates. Management International Review, 56, 283-301.

Froese, F. J., Sekiguchi, T., \& Maharjan, M. P. (2018). Human resource management in Japan and South Korea. In F. L. Cooke \& S. Kim (Eds.), Asian HRM handbook (pp. 275-294). New York: Routledge.

Hemmert, M. (2020). Does Korean-style management have a future? Asian Business \& Management. https://doi.org/10.1057/s41291-019-00062-6.

Jiang, K., Lepak, D. P., Hu, J., \& Baer, J. C. (2012). How does human resource management influence organizational outcomes? A meta-analytic investigation of mediating mechanisms. Academy of Management Journal, 55(6), 1264-1294.

OECD. (2020). Labour compensation per hour worked (indicator). https://doi.org/10.1787/251ec2da-en

Publisher's Note Springer Nature remains neutral with regard to jurisdictional claims in published maps and institutional affiliations. 